\title{
Российское отходничество: вехи многовековой истории ${ }^{1}$
}

\begin{abstract}
ю. М. плюснин, доктор философских наук, кандидат биологических наук, Национальный исследовательский университет «Высшая школа экономики», Москва. E-mail: jplusnin@hse.ru
\end{abstract}

Аннотация. Отходники - самоназвание внутренних временных трудовых мигрантов в России, которые могут быть как самодеятельными предпринимателями, так и наёмными работниками. Ключевые особенности отходников: 1) жители сельской местности и малых городов, ищущие работу в столицах и центрах промышленного развития (в последнем случае синоним - вахтовики); 2) не намерены менять место постоянного жительства ради работы; 3) основная трудовая мотивация состоит в повышении благосостояния семьи; 4) самостоятельность, самодеятельность, инициатива- основные трудовые качества отходника.

В статье кратко рассмотрена пятивековая история российского отходничества и выделены основные причины отхода в имперский и современный периоды, а также факторы, стимулирующие или подавляющие отхожую активность провинциального населения. Представлены авторские оценки современной численности отходников и оценки других исследователей, позволившие описать вековую динамику численности. Даны оценки структуры отходничества по видам занятости с 1990-х годов до последнего времени. Описана эволюция современного отходничества, особенностями которой являются динамизм, изменчивость и экспансия. Автор имеет основания полагать, что отходники - авангард пресловутого «нового опасного класса - прекариата» в современной России.

Ключевые слова: неформальная экономика; самозанятость; возвратная сезонная трудовая миграция; отходники; история российского отходничества; структура и виды отхожих промыслов

Российские отходники - специфическая группа трудовых мигрантов - внутренних временных (возвратных) самодеятельных или наёмных работников. Эти трудовые мигранты имеют характерные отличия как от трансграничных циркулярных, так и от типичных сезонных сельских мигрантов (хотя немногие

${ }^{1}$ В статье частично приводится текст автора из опубликованной монографии Плюснин Ю. М., Заусаева Я.Д., Жидкевич Н. Н., Позаненко А. А. Отходники. М.: Новый хронограф, 2013. Глава 1.

Полевые исследования отходничества проводились в 2009-2016 гг. при финансовой поддержке Фонда «Хамовники» (грант № 2011-001).

На заключительном этапе теоретического обсуждения полевых материалов исследование получило финансовую поддержку Научного фонда НИУ ВШЭ (грант № 17-01-0027, 2017-2018 и грант № 19-01-067, 2019-2020) в рамках Программы «Научный фонд Национального исследовательского университета «Высшая школа экономики» (НИУ ВШЭ)» и в рамках государственной поддержки ведущих университетов Российской Федерации «5-100».

Я признателен моим коллегам, вместе с которыми мы осуществляли эмпирическое исследование отходничества: А. А. Позаненко, Н. Н. Жидкевич, Я. Д. Заусаевой. 
из них заняты на сезонных или сельхозработах). Безусловно, отличны они и от гастарбайтеров. В России термин «отходники» используется уже не менее 400 лет.

Главные отличительные признаки современного отходничества, которое, по сути, является особым видом самодеятельной промысловой активности населения, аналогичны характеристикам несельскохозяйственного промышленного отходничества второй половины XIX - первой трети XX вв.:

1) источник отхода - провинция (в основном сельские районы и малые города); направление - столичные города и промышленные центры, Север и Сибирь;

2) важнейший признак отходника - отсутствие намерения менять место постоянного жительства ради работы;

3) трудовая миграция как мотив чаще всего обусловлена не нуждой, а повышением благосостояния семьи отходника;

4) самостоятельность, самодеятельность, инициатива исходят от самого работника, и этим он решительно отличается от наёмного работника-резидента.

Отходничество было очень широко распространено в имперской России XIX - начала XX вв. В нечернозёмных губерниях среди мужского крестьянского населения зимнее и весеннее отходничество было почти поголовным. При этом на Урале и в Сибири отход практически не был известен. В середине XIX в. отхожими промыслами занимались около 3-5 млн крестьян, а после 1860-х годов количество отходников возросло не менее чем вдвое. К концу 1920-х гг. доля мужского населения, отправлявшаяся в отхожие промыслы, местами достигала 80-90\% [Владимирский, 1927. С. 76-121]. Однако к 1930-м годам феномен внезапно исчез на пять десятилетий. Возродилось отходничество лишь в середине 1990-х годов и в течение четверти века быстро нарастало. В наше время численность отходников сопоставима с их количеством в конце имперского периода более 15 млн (рис. 1).

С точки зрения автора, особенности трудового поведения и мотивации отходников, их социально-демографические характеристики делают отходничество новым важным фактором экономической и политической жизни России, служащего базой для «нового опасного класса - прекариата» [Стэндинг, 2014]. Однако роль отходничества была значима и в другие периоды 
истории России, в частности, есть основания видеть в этом явлении один из важных факторов социальных трансформаций столетней давности.

Млн чел.

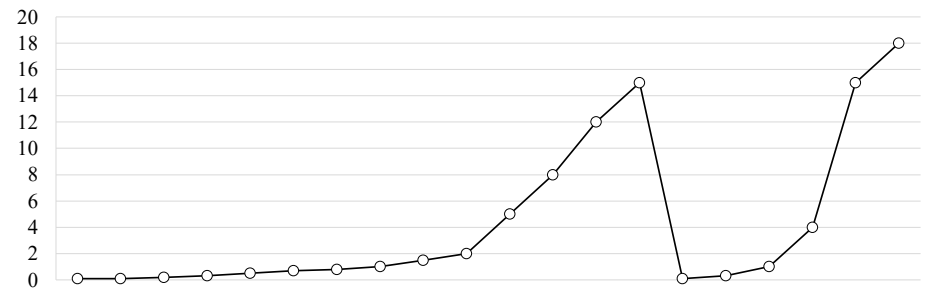

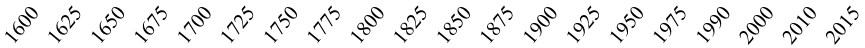

Источник рис. 1, 2: Plusnin et al., 2015. Р. 51, 52.

Примечание. Динамика численности с начала XVII в. представлена на основании оценок разных авторов.

Puc. 1. Развитие российского отходничества в имперские, советские и нынешние (постсоветские) времена (1600-2015 гг.), млн чел.

Изучая продолжительное время современное российское отходничество, автор пришёл к выводу о быстрых изменениях в этом виде трудовой активности. Но для понимания логики структурных преобразований, имеющих место в наши дни, следует рассмотреть и основные вехи предшествующего развития отходничества в Российской империи.

\section{Отходничество в Российской империи}

Отхожие промыслы существовали в Русском царстве ещё в XVI-XVII вв. [Кулишер, 2004. С. 353-381, 415-424]. Вероятно, важнейшим фактором, обусловившим появление и развитие этого феномена, стала быстрая территориальная экспансия, увеличившая пространство России в два раза за годы правления Ивана IV. Такое расширение территории, наряду с формированием крепостной системы, не могло не изменить форм экономического поведения населения.

В начале XVIII в. наиболее ощутимый толчок к развитию отходничества дало массовое принудительное перемещение крестьян на петровские «великие стройки» и великие войны (введение рекрутского набора). Исследователи XIX-XX вв. 
практически единодушно отвели реформам Петра I решающую роль в появлении массового отходничества.

Отходничество как особая модель экономического поведения населения складывалось при двух обязательных условиях: прикрепление крестьянина к земле и невозможность прокорма семьи на месте, вынуждающая искать сторонние источники существования. На плотно заселённых, но бедных нечернозёмных землях империи было невозможно прокормиться уже к XVIII в. Крестьянские семьи поневоле отправляли часть своих членов (почти всегда молодых мужчин и мальчиков) в отхожие промыслы в соседние уезды и города. Государство, помещики или сельский мир в XVIII в. определённо «осознают» проблему перенаселения и предпринимают соответствующие действия ${ }^{2}$. Государство отправляет крестьян на «стройки века» и «тратит» в войнах. Сельская община отпускает в города отдельных умельцев для денежных заработков, что позволяет платить государевы налоги. Помещики начинают осознавать, что оброк выгоднее барщины, и отпускают на промыслы всё большее число крепостных, и даже способствуют обучению их ремёслам.

Благодаря этим факторам отходничество быстро распространяется в наименее сельскохозяйственно продуктивных центральных и северных губерниях Российской империи. В центральных губерниях движителем отхода больше выступает помещик, а в северных - скудость урожаев, хотя в некоторых губерниях (например, во Владимирской, Костромской, Ярославской, Нижегородской) с равной силой действовали оба фактора, и именно эти территории являлись основными источниками отхода в обе столицы.

К началу XVIII в. численность отходников оценивалась примерно в 1 млн чел. [Карышев, 1896]. По моим расчётам это составляло более половины (!) крестьян-мужчин в возрасте

\footnotetext{
2 Хотя известны и противоположные примеры. Например, по воспоминаниям С. Ю. Витте, императорская семья противилась освобождению помещичьих крестьян, поскольку при высокой плотности населения и его крепостной зависимости «земля дорог’а, а труд дёшев».

${ }^{3}$ Исходя из довольно грубого предположения о неизменности половозрастного состава (49\% мужчин, из них 44\% в возрасте 20-59 лет) крестьянского населения и его доли (примерно 84-87\%) в составе всего населения Европейской России (73\% от всего населения империи численностью около 14 млн чел. или менее к 1720-м годам).
} 
от 20 до 59 лет 4 , проживающих в сельской местности Европейской России в начале XVIII в. (1,87-1,90 млн чел.).

Латентное развитие отходничества началось в XVIII в. и продолжалось до середины XIX в. Вначале главным стимулом послужило данное помещикам право собирать подушную подать со своих крепостных (1731 г.). Через 30 лет (1762 г.) вышел «Манифест о даровании вольности и свободы российскому дворянству», освободивший помещиков от обязательного несения государственной и военной службы, что переместило значительную их часть в деревню и заставило искать средства для существования среди своих крестьян. Разрешение помещикам закладывать имения вместе с крестьянами ещё больше стимулировало развитие отхода. А спустя столетие Манифестом об освобождении крестьян 1861 г. завершился процесс оформления отходничества как основной, наряду с сельским хозяйством, модели жизнеобеспечения крестьянского населения на значительной территории страны (Кулишер, 2004; Burds, 1998).

Первоначально вызванная исключительно нуждой, отхожая активность очень скоро становится главным условием благополучия крестьянина. Этому ещё более способствовал промышленный рост конца XIX в., завершивший длительный экономический кризис 1860-1880-х годов [Суханов, 1913; Ленин, 1971; Фёдоров, 2010]. К началу ХХ в. отходничество, дополнительно стимулированное столыпинскими реформами и кооперативным движением в провинции, достигло пика развития [Данилов, 1974; Северо-Запад.., 2008].

Необходимо обратить внимание, что кооперация в России в первые десятилетия XX в. по своим темпам и масштабам значительно превосходила аналогичные процессы в Европе именно вследствие развития отходничества, которое способствовало и развитию кустарной промышленности.

Можно оценить численность отходников в 1920-е годы примерно в 10-12 млн чел. на основании статистики выдачи паспортов и билетов крестьянам [Владимирский, 1927; Минц, 1926]. Используя тот же метод, но основываясь на данных

\footnotetext{
${ }^{4}$ В отхожих промыслах мужчины старше 60 лет не участвуют, как в прежние времена, так и сейчас. И хотя до революции в отходе участвовало немало подростков и юношей, но их доля в составе всех отходников была невелика (хотя точно неизвестна).
} 
Всероссийской переписи 1897 г. и информации по структуре населения за 1910 г., я оцениваю долю отходников среди всех крестьян-мужчин Европейской России в 47-56\% от 21 млн 542 тыс. мужчин в возрасте 20-59 лет, т.е. те же 10-12 млн чел. Поскольку в чернозёмных губерниях, на юге России, имел место и сезонный земледельческий отход, вызванный причинами малоземелья, оценки авторов начала XX в. о почти поголовном отходе мужчин не кажутся нереальными.

\section{Короткая история отходничества в советский период}

Отношение государства к отходничеству менялось на протяжении российской истории. Если в имперский период отходники в большей степени зависели от помещика и сельского мира, позже - только от общины или были предоставлены себе, то в первые советские годы появилась зависимость от государства.

Самые первые инициативы регулировать отход населения исходили ещё от местной власти. В Сызранском уезде Нижегородской губернии в 1870-х гг. было предложено ввести институт «земских агентов», которые должны были «прислушиваться к биению народного пульса и присматриваться к состоянию рынка труда в Заволжье с тем, чтобы в случае необходимости предотвращать чрезмерный наплыв рабочей силы с горной стороны Волги в Нижний Новгород, в Москву или Петербург» [Мордовцев, 1877]. На губернском уровне эта инициатива в то время не была поддержана. Однако уже к 1920-м годам отходничество стало рассматриваться не только как «следствие аграрного перенаселения» [Минц, 1929], но и как едва ли не единственный способ его преодоления [Суворов, 1968; Рындзюнский, 1970; Северо-Запад.., 2008].

Советской властью отходничество воспринималось в целом как явление прогрессивное, поскольку «...по своему социально-профессиональному облику крестьяне-отходники являлись прямым и непосредственным резервом рабочего класса страны» [Андрюшин, 2012. С. 232]. Но с другой стороны, этот феномен вызывал беспокойство Наркомата труда, специальной задачей которого была борьба с безработицей в городах, а основным источником её как раз было отходничество [Данилов, 1974]. 
Приток сельского населения в города «... был настолько мощным, что одной из официальных целей введённой в 1932 г. паспортной системы была “разгрузка городов”» [Андрюшин, 2012. С. 205]. Интересно, что паспорта первоначально вводились временно и только в четырёх столичных городах - Москве, Ленинграде, Харькове и Киеве, поскольку именно они испытывали наибольшие трудности в связи с двух-трёхкратным ростом численности жителей.

Попытки ограничить крестьянское отходничество вскоре вступили в противоречие с задачами индустриализации страны. В правительстве считали, что для реализации планов промышленного развития имеющихся масштабов отходничества недостаточно. Возникла необходимость в инвентаризации и институционализации этого явления. Поменяли название - отходник стал «сезонником». Изменили суть, превратив свободную инициативу в оргнабор рабочей силы. Для этого понадобилось несколько специальных постановлений ЦИК и СНК 1930-1934 гг. ${ }^{5}$ В результате очень скоро отходничество стало только историческим феноменом.

В период с $1931^{6}$ по 1991 гг. отходничество существовало как глубоко маргинальный феномен в изрядно извращённом виде. Единственной его формой, получившей некоторое одобрение власти, оказалась сезонная «вербовка» работников из трудоизбыточных районов в южных и западных советских республиках (Молдавия, Украина, Армения, Узбекистан, Киргизия) на лесоразработки в северные лесные области (Архангельскую, Карелию, Коми, Вологодскую, Костромскую, Пермскую) и Сибирь, где постоянно не хватало рабочих рук ${ }^{7}$. «Вербовка» в лесопункты началась с конца 1940-х годов и достигла пика в 1950-е годы. Поскольку она охватывала преимущественно сельских жителей, работавших в колхозах и совхозах, а основные работы на лесозаготовках производятся зимой, такая форма занятости приобрела

\footnotetext{
${ }^{5}$ Постановления СНК и ЦИК от 16.03.1930 г., от 30.06.1931 г., от 17.03.1933 г., от 19.09.1934 г.

${ }^{6}$ После Постановления Центрального исполнительного комитета и Совета народных коммисаров СССР от 30.06.1931 «Об отходничестве» и Постановления СНК СССР от 17.03.1933 «О порядке отходничества из колхозов».

7 Людей, набранных таким образом, так и называли - «вербованными»; под этим прозвищем они и проходили в тех населённых пунктах, куда их привозили на работы.
} 
характер сезонного труда с регулярным возвратом домой для участия в сельскохозяйственных работах.

Очень скоро колхозы и совхозы перехватили инициативу и стали сами отправлять в лесопункты целые бригады работников, которые за зиму не только зарабатывали денег для семьи, но и заготавливали пиломатериал, остродефицитный на юге, для своего колхоза и односельчан. Нередко теперь уже бывшие «вербованные», превратившиеся в командированных колхозом, участвовали в строительстве различных объектов в лесных посёлках и сёлах.

Когда потребность в лесозаготовителях стала снижаться (к концу 1970-х), процесс утратил организованный характер: появились самодеятельные бригады лесозаготовителей и строителей, которые стали ездить в уже знакомые места на заработки. С изменением сути отношений изменилось и наименование: таких работников стали называть «шабашниками», поскольку они самостоятельно находили для себя дополнительные виды заработка - «шабашку».

В 1980-е годы ${ }^{8}$ практика строительных бригад «шабашников» распространилась настолько, что стала привлекать внимание исследователей, экономистов и социологов [Шабанова, 1986].

По сути, сезонные лесозаготовители зимой («вербованные») и, позже, строители летом («шабашники») не были настоящими отходниками, поскольку не располагали всеми признаками именно этого вида трудовой миграции. «Вербованные» хотя и отъезжали из дома на сезонные работы, не были самодеятельными и инициативными, их командировало хозяйство для выполнения поставленных ему задач. «Шабашники» отправлялись на заработки не по необходимости, а ради дополнительного, временного и случайного приработка, такая работа не являлась для них регулярной (за исключением отдельных специалистов и бригадиров, которые были настоящими отходниками). Ни в общественном сознании,

\footnotetext{
8 1980-е годы - единственное десятилетие советского времени, когда наблюдалось процветание села: повсюду строились не только фермы и комплексы, но и дороги, и дома для колхозников. Кроме того, колхозы и совхозы располагали большими, чем предприятия городов, свободами в распоряжении средствами, выделяемыми на хозяйственное строительство. Именно поэтому в эти годы почти в каждом колхозе и совхозе трудились летом «вербованные» и «шабашники» из западных и южных советских республик.
} 
ни в сознании учёных (за немногими исключениями) эти феномены не фиксировались как особый вид трудовой миграции.

Повторно отходничество возродилось в начале 1990-х годов [Шабанова, 1992], превратившись со временем в массовую модель экономического поведения населения. Однако возобновилось отходничество не из нечернозёмных областей Европейской России, а из постсоветских республик, которые ранее были основным источником «вербованных» и «шабашников». Впрочем, через несколько лет это экономическое движение захватило и население областей традиционного отхода. Кроме того, в последние годы отход (под наименованием «вахты») стал преобладать в сёлах и малых городах в сибирских областях, чего ранее не бывало.

\section{Два этапа в развитии современного отходничества}

Хотя современное российское отходничество существует менее тридцати лет, оно успело пройти уже два этапа. Первый из них следует назвать «периодом роста», он заключался в возрождении и нарастании массового отхода прежде всего и исключительно в малых городах европейской части. Второй - «период экспансии», характеризуется смещением источников отхода «вглубь» (в сельскую округу) и «вширь» (захватывая всё новые и новые регионы страны, прежде всего, восточные).

Важнейшая особенность первого этапа (1990-2000) заключалась в сравнительно быстром возникновении отхода из малых городов в столицы, Москву и Санкт-Петербург. Прежде всего на возобновление отходничества повлияло отсутствие рынка труда в малых городах в период кризиса начала 1990-х. При низкой мобильности рабочей силы (трудовая миграция была совершенно не развита) и отсутствии почти всякой работы, усугублённых неразвитостью (в малых городах) подсобных хозяйств, большинство семей стали спешно искать новые источники жизнеобеспечения. Наиболее прибыльным среди них оказался отход в крупные города. И уже к началу 2000-х годов он стал наиболее массовым видом экономической активности населения в российской европейской провинции.

Вторым важнейшим фактором возобновления отходничества явилась невозможность для семей отходников переселиться 
ближе к месту их новой работы. Источником этого фактора были общеизвестные особенности российской жилищной системы: советская «квартирная крепость», полная неразвитость рынков арендного жилья и ипотеки. «Квартирная крепость» и сейчас влияет на направление и видовой состав отхожих промыслов из малых городов: без такой «прикреплённости» отход не имел бы нынешних масштабов.

Первый этап развития современного отходничества был спонтанный, вызван нуждой, захватил преимущественно население малых городов, оказавшихся в «тисках» между крупными промышленными и деловыми центрами, где всегда имелись возможности заработка, и деревней, располагающей источниками самообеспечения продуктами питания. Ни того, ни другого у малого города не было в 1990-х годах.

Надо отметить, что на первом этапе базу отходников составляли профессионалы - строители, плотники, столяры, водители, механики, инженеры. В то трудное время, в 1990-е годы, в промышленных центрах и даже столицах востребованность работников в сфере материального производства была ещё много выше, чем в сфере услуг (к середине 1990-х годов доля работников в этом сегменте экономики достигала $54 \%$ и более, тогда как к концу 2000-х годов сократилась до менее чем $20 \%$, при росте доли сферы услуг до 70-75\%). К концу первого этапа численность отходников всего за десятилетие возросла до 7-10 млн чел. (18-26\% мужчин трудоспособного возраста) (рис. 1).

На втором этапе (2000 г. - наши дни) отходничество распространяется в трёх направлениях: из малого города в его сельскую округу, из центральных областей - на восток страны, за Урал, в Сибирь. Кроме того, отход перестаёт быть исключительно мужским делом: в течение последнего десятилетия быстро возрастает доля женщин-отходников.

Смещение мест отхода из районного центра в окружающие деревни вызвано экономической стабилизацией 2000-х. Во многих малых городах были восстановлены промышленные предприятия, возникли новые места трудоустройства, которые вернули часть отходников домой. Кроме того, в результате «достраивания вертикали власти до уездного уровня» в районных центрах значительно увеличилось количество «бюджетников». 
Их доля в составе трудоспособного населения, занятого в местной экономике, достигает $40-70 \%{ }^{9}$. Все это способствовало сокращению отходничества в малых городах. На рабочие места в столицах и промышленных центрах, занимаемые ранее отходниками из районных городов, устремились жители окрестных деревень.

Одновременно происходил сдвиг мест отхода на восток. По различным причинам. Ранее отходничество (за исключением дальнего извоза) было чуждо богатым сибирским поселениям (иная точка зрения: [Ремнев, Суворова, 2010]). Местные жители долгое время не нуждались в поиске дополнительных заработков на стороне. Теперь же отходничество стало в Сибири повсеместным и порой более масштабным, чем на западе страны. При этом структурно сибирское отходничество отличается от европейского. Во-первых, главным образом оно затрагивает жителей посёлков и деревень, реже - малых городов (возможно, это мнение автора, основанное на эпизодических наблюдениях, ошибочно). В последние годы в отход стали массово идти жители моногородов Урала и Сибири. Во-вторых, сибирский отход «смыкается» с вахтой, как более характерной для востока страны формой трудовой миграции. Особенность вахты - наем по официальным объявлениям работодателя и формирование им бригады на месте. В отличие от вахтовых наборов, сибирские отходники нанимаются самостоятельно, и бригады комплектуют своими силами, взаимодействуя с работодателем на уровне артели.

Третьей важной особенностью второго этапа развития отходничества является возрастание доли женщин. Если в 1990-е годы женщины практически не шли в отход, то с конца 2000-х их численность стала возрастать. Отходницы-в основном женщины 40-50 лет и старше, вырастившие детей и имеющие возможность оставить семью на две недели-месяц или даже год, уезжая на заработки. Значительная часть женщин занята в сфере услуг (продавцы, торговки, уборщицы, домашняя прислуга, консьержки) или социального воспроизводства (медсёстры, няни, учителя). Однако

\footnotetext{
9 Такие значительные доли «бюджетников» неудивительны, поскольку отнесены не ко всему трудоспособному населению, а только к занятому в местной экономике и учтённому статистикой. При этом доля неучтённого (в экономике) населения может составлять от $10-15 \%$ до $30 \%$ и $50 \%$.
} 
всё чаще они нанимаются на фабрики и заводы; возрастает поток женщин и на северные вахты.

\section{Состав современных отходников}

В Российской империи большинство крестьян-отходников были «мелкими предпринимателями» - кустарями, предлагающими на местных рынках собственную продукцию. Многие, если не все крестьяне-кустари, были одновременно и отходниками, а доходы от этих промыслов были очень значительны. По некоторым оценкам [Деларов, 1928], в нечернозёмных губерниях Европейской России условный чистый доход хозяйства формировался за счёт промыслов более чем на четверть. В губерниях же основного отхода доля такого дохода была более половины [Владимирский, 1927].

Современный отходник стал больше наёмным работником; тогда как отходниками-предпринимателями можно считать, например, столяров, плотников или промышленных строителей. Кустарное производство бытовых предметов теперь находится в так называемом «этноформате». Большинство современных отходников средней и высокой квалификации работают в промышленности, на строительстве и на транспорте. В сфере услуг (охрана, торговля, прислуга) много неквалифицированных отходников.

Основных видов занятий отходников немного: по результатам наших интервью мы зафиксировали лишь около полутора десятков видов отхожей деятельности. Напротив, в дореволюционные годы в каждом крупном селе насчитывалось до полусотни видов отхожих занятий [Владимирский, 1927]. Нынче отходники трудятся в основном в сферах строительства, транспорта, включая дальний извоз, бытовых услуг, торговли. Очень популярен охранный бизнес: многочисленная армия охранников в офисах и на предприятиях крупных городов почти исключительно представлена жителями ближайших областей. На крупные предприятия отходники, как правило, нанимаются по артельному принципу, поэтому и трудоустройство неофициальное: на каждого легального работника приходится 8-9 его родственников и приятелей, которые формально не трудоустроены и выполняют чаще всего вспомогательные виды работ. 
Реально учесть численность этой разношёрстной когорты пока совершенно невозможно. По моим весьма грубым оценкам, источниками которых являются данные о численности трудоспособного мужского населения российской провинции (около 20-23 млн чел.) и выборочные данные о доле населения, не занятого в местной экономике (которая варьирует от 15 до $47 \%$ и более), отходничество в России на 2015 г. практиковали около 10-15 млн чел., сейчас, скорее всего, их больше. Из примерно 44 млн мужчин трудоспособного возраста доля отходников составляет от $1 / 4$ до $1 / 3$ - т.е. и в наши дни, как и два-три века назад, отхожие промыслы - наиболее массовая форма занятости населения.

Особенно велики по численности две профессионально компактные группы отходников - охранники и дальнобойщики. Охранники сейчас считаются обязательными не только в многочисленных фирмах, торговых центрах, учреждениях, но и порой во дворах многоэтажных домов. По грубым оценкам, охранников в стране более 3 млн чел. Почти все они - жители провинции из окружающих столицы областей, ездят 2-недельными вахтами на расстояние до 500-700 км от места жительства («Всю Москву охраняет Мордовия!»).

Отходники-дальнобойщики - ещё одна массовая категория современного российского отходничества. Российский «дальнобой» складывался в 1990-е годы, а в начале 2000-х получил очень интенсивное развитие, до сих пор ещё не оценённое. Вероятно, основными причинами этого стали «закручивание нормативных гаек», нарастание сбоев в обеспечении перевозок и непомерное повышение тарифов железнодорожным монополистом - ОАО «РЖД».

В настоящее время «дальнобой» - это огромная, хорошо укомплектованная кадрами, обеспеченная техникой и связью, организованная армия перевозчиков. По самым приблизительным оценкам, численность дальнобойщиков составляет от 3 до 5 млн чел. Не менее половины из них - индивидуальные предприниматели, работающие автономно, на собственных автомобилях (которые часто они сами же и обслуживают), самостоятельно находя грузоотправителей. Другую половину составляют те, кто нанимается водителем в специализированную фирму-перевозчик, получает автомобиль, обслуживание 
которого обеспечивают специальные бригады слесарей, а ведение по трассе - технические команды.

Но и те и другие дальнобойщики используют в своей работе уже сложившуюся и развитую систему диспетчерского обслуживания, которая, вероятно, уже становится единой. Развитие частной диспетчерской службы способствовало сплочению дальнобойщиков и усилило их профессиональную замкнутость. Заказы на перевозки перестали быть случайными. Тенденция развития автоперевозок последнего десятилетия в России идёт в общем русле, хорошо известном на примере США - далеко не добровольной организации независимых водителей в транспортные компании [Wyckoff, 1979].

Таким образом, по характеру занятий современные отходники составляют четыре большие категории: квалифицированные плотники-строители и промышленные инженеры и рабочие (включая нынешних вахтовиков); водители-дальнобойщики; охранники, большей частью неквалифицированные работники; различные работники в сфере услуг, также в основном неквалифицированные. На рисунке 2 показана оценочная динамика численности разных категорий работников в составе отходников. Млн чел.

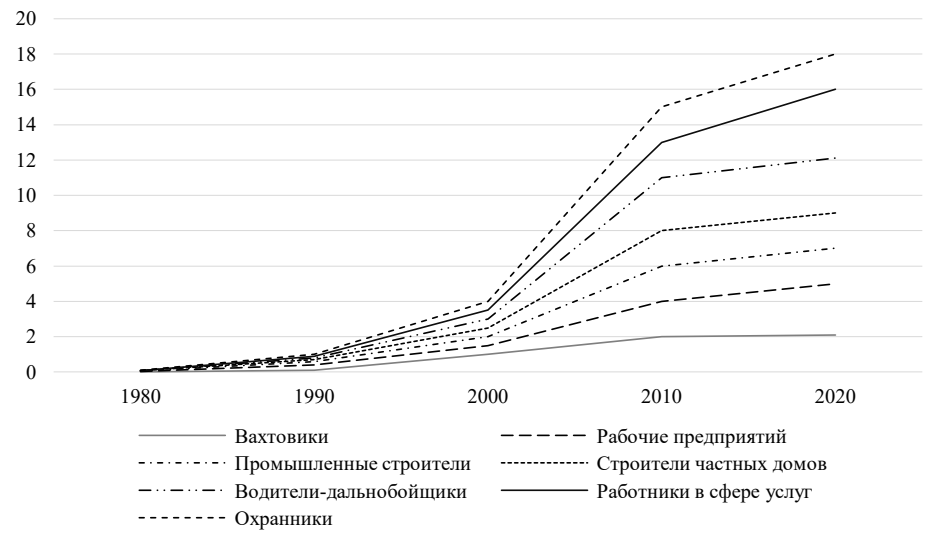

Puc. 2. Состав отходников (накопленные доли разных профессиональных групп) и его динамика в современный период (1985-2015 гг.), млн чел. 


\section{Характерные черты современного отходника}

Несмотря на временной разрыв в целое столетие, для отходничества характерна высокая консервативность видов промыслов. Сегодня отходники освоили и воспроизвели все основные профессии, характерные некогда для традиционных территорий отхода. Такая практика повсеместна, не составляет уникальности, например, для Костромской, Вологодской или соседних областей. Отходники этих регионов заняты главным образом строительством деревянных домов, как и их прадеды. Рязанские, пензенские, мордовские отходники нанимаются чаще охранниками; ранее они были чернорабочими, подёнщиками, бурлаками. Отходники из Любима в Ярославской области, как и прежде, нанимаются в качестве официантов (бывшие половые) в рестораны Петербурга.

Направления отхода иные, чем раньше, однако за столетие изменилось и административно-территориальное деление России, и с учетом этого фактора по географическим траекториям отход тоже консервативен. Население северных губерний, Заволжье шли преимущественно в Санкт-Петербург; нынешние отходники едут в Москву (в столицу в обоих случаях). То же происходит и с областными городами: при смене областного центра меняется и направление отхода из районов (мордовские отходники шли в Пензу, Нижний, Москву, нынче же едут в Нижний, Москву и Сызрань). География отходничества несколько расширилась. В XIX в. дальние отходы были, например, из Каргополя и Великого Устюга в Кронштадт и Тифлис; в наши дни отходники едут из Касимова в Якутию добывать алмазы, из Алагира в Осетии в Норильск добывать никель.

За столетие выросли на порядок скорости перемещения отходников, и сами перемещения стали более частыми и дальними. На расстояниях до 100-150 км обычна маятниковая миграция, а не прежний отход на одну-две недели; на вахты на расстояния до 700 км трудовые мигранты едут на одну-две недели, а не как раньше - на полгода-год. На расстояния более 1 тыс. км уезжают на месяц-два, а когда удалённость вахты составляет 2-5 тыс. км, на полгода-год.

Большинство нынешних отходников, как и раньше, стараются далеко от дома не уезжать. До половины их ищут заработок в радиусе 200-300 км от дома. На более дальние расстояния, 
до 500-800 км, что соответствует примерно полусуточному перемещению на поезде или автомашине, уезжают около четверти. Остальные готовы мириться с тем, что время на дорогу составляет существенную долю рабочего времени (оценочно: более $1 / 10)$.

Средние доходы отходников, безусловно, выше заработка их соседей, остающихся дома, но не настолько, как обычно представляется. Приведу наши данные о заработках отходников в 2010-2015 гг. [Plusnin et al., 2015], до настоящего времени они не изменились. Кардинально доход зависит от квалификации и вида деятельности. Самозанятые строители-плотники за 2-3 месяца летнего сезона зарабатывают до полумиллиона и более. В промышленности, на транспорте и промышленном строительстве получают меньше - от 50 до 70 тыс. руб. в месяц, но работают почти круглый год. Неквалифицированный труд в сфере услуг приносит до 20-25 тыс.; работа охранником - 15 тыс. за две недели в месяц.

В среднем квалифицированный отходник получает за сезон около 300-500 тыс. руб., неквалифицированный - 150-200 тыс. Из этой суммы следует вычесть расходы, необходимые во время работы (около 5-15 тыс. руб. в месяц). Следовательно, при среднем заработке в 25-40 тыс. руб. неквалифицированный отходник домой везет обычно не более 20-25 тыс. в месячном пересчёте. Высококвалифицированные специалисты привозят 50-70 и более тысяч, при этом нередко они не тратятся на питание и проживание. Для сравнения: среднее жалование «бюджетника» в провинции составляет 100-150 тыс. руб. в год, зарплата продавщицы - не более 80-100 тыс., а рабочий на пилораме зарабатывает не более 200 тыс. Поэтому отхожая деятельность остаётся выгодной на местном уровне главным образом в сравнении с соседями-«бюджетниками».

Статус отходника в местном обществе безусловно высок, это подтверждают все наши полевые данные [Plusnin et al., 2015]. А вот их общественно-политический статус неопределёнен, что часто не позволяет им пользоваться многими ресурсами, к которым допущены «бюджетники» или работники, занятые в местной экономике. Причина заключается в «удалённости от государства» людей с таким образом жизни [Плюснин, 2016]. Большинство отходников находятся не только 
вне местной экономики (что очевидно), но и вне экономики вообще, поскольку заняты неформально и не регистрируют свою деятельность, минуют государство, оказывая услуги обществу, не платят налогов, не участвуют в социальных проектах.

Государству не видны плоды их трудов, оно не отслеживает перемещения их по территории страны, они не подконтрольны, следовательно, не «закрепощены». Хотя, если принять во внимание, что до $2 / 5$ всех российских домохозяйств в той или иной мере заняты в отхожих промыслах, объём «теневой» деятельности представляется чрезвычайно большим (что и фиксируется многими исследованиями [Неформальная экономика..., 1999; Радаев, 1999; Барсукова, 2003, 2004; Барсукова, Радаев, 2012; Нестандартная занятость..., 2006; В тени регулирования, 2014]. В результате имеет место парадокс «невидимости» огромного по масштабам феномена российской действительности. Но встаёт вопрос: действительно ли этот «огромный невидимка» так уж неуловим? Может быть, самозанятый, самодеятельный работник трудовой мигрант-отходник государству просто не нужен? Ведь он почти исключён из государственных социальных программ, экономически неконтролируем, а ко всему прочему выброшен и из политической жизни. Власти он полезен разве что в качестве учётной демографической единицы.

Однако этот «невидимка» выпирает сквозь любые щели и дыры всех видов российских институтов, утверждая своим присутствием для многих уже вполне очевидный факт: на наших глазах формируется новая социально-профессиональная группа, которую, вслед за некоторыми социологами и экономистами, можно диагностировать в качестве «нового опасного класса», уже имеющего и собственное имя - прекариат [см.: Стэндинг, 2014; Тощенко, 2018], о чём я специально писал ранее [Плюснин, 2016].

Таким образом, сезонный несельскохозяйственный отход провинциальных жителей в поисках работы в крупные города нашей страны - очень давняя практика, существующая не менее 400-500 лет. Чрезвычайная распространённость, массовость и разнообразие форм такого экономического поведения позволяют 
считать его основным способом экономической самоорганизации населения и базовой моделью жизнеобеспечения, наряду и вместе с частным подсобным хозяйством. Однако, в отличие от этого последнего, отходничество создаёт социально-политические риски, оказываясь ведущим условием нарастания социальной напряжённости. Так случилось на рубеже XIX - XX века; риски были преодолены большими жертвами и усилиями только с помощью проектов тотальной индустриализации и коллективизации.

В начале XXI века отходничество приобрело столь же массовый характер, как и сто лет назад. Но если прежде за спиной отходника было его натуральное хозяйство, то теперь отхожий промысел стал основным, если не единственным источником дохода семьи для очень многих людей. При этом преимущественно наёмный и неформальный характер отхожих промыслов и отсутствие государственных социальных гарантий для подавляющего большинства отходников переводят их в статус «прекариата». А этому «новому классу» снова есть за что бороться.

\section{Литература}

Андрюшин Е.А. Из истории трудового законодательства СССР и политики советского правительства в области трудовых ресурсов. М.: Новый хронограф, 2012. $464 \mathrm{c}$.

Барсукова С. Ю., Радаев В.В. Неформальная экономика в России: краткий обзор // Экономическая социология. 2012. Т. 13. № 2. С. 99-111.

Барсукова С. Ю. Неформальная экономика: понятие, структура // Экономическая социология. 2003. Т. 4. № 4. С. 15-36.

Барсукова С. Ю. Неформальная экономика: экономико-социологический анализ. М.: Изд-во ГУ ВШЭ, 2004.

В тени регулирования: неформальность на российском рынке труда / Под ред. В.Е. Гимпельсона и Р.И. Капелюшникова. М.: Изд. дом Высшей школы экономики, 2014. $536 \mathrm{c}$.

Владимирский Н. Н. Отход крестьянства Костромской губернии на заработки. Кострома: Издание Костромского губстатотдела, 1927. 204 с.

Данилов В.П. Крестьянский отход на промыслы в 1920-х гг. // Исторические записки. 1974.

Деларов Д. И. Северная область и её место в народном хозяйстве СССР // Север, Вологда, 1928. № 7-8. С. 135-160.

Карышев Н.А. К изучению наших отхожих промыслов // Русское богатство, 1896. № 7. С. 1-24.

Кулишер И.М. История русского народного хозяйства. Челябинск: Социум, 2004. $743 \mathrm{c}$.

Ленин В.И. Развитие капитализма в России. Процесс образования внутреннего рынка для крупной промышленности / Ленин В. И. Полн. собр. соч. Изд. пятое. М.: Изд-во политической литературы, 1971. Т. 3. 610 с. 
Мини Л.Е. Аграрное перенаселение и рынок труда в СССР. М.-Л.: ГИЗ, 1929.

Мини Л.Е. Отход крестьянского населения на заработки в СССР. М.: Вопросы труда, 1926.

Мордовцев Д.Л. Десятилетие русского земства. 1864-1875. СПб, 1877. 86 с.

Нестандартная занятость в российской экономике / Под ред. В.Е. Гимпельсона и Р.И. Капелюшникова. М.: Изд. дом ГУ-ВШЭ, 2006. 400 с.

Неформальная экономика. Россия и мир / Под ред. Т. Шанина. М.: Логос, 1999.

Плюснин Ю.М. Вдали от государства: отходники и власть в современной России // Вопросы государственного и муниципального управления. 2016. № 1. С. $60-80$.

Радаев В.В. Теневая экономика в России: изменение контуров // Pro et Contra, 1999. T. 4. № 1 (10). C. 5-24.

Ремнев А.В., Суворова Н.Г. Управляемая колонизация и стихийные миграционные процессы на азиатских окраинах Российской империи // Полития, 2010. № 3-4 (58-59). С. 150-191.

Рындзюнский П.Г. Крестьянский отход и численность сельского населения в 80-х годах XIX в. // Проблемы генезиса капитализма. М.: Наука, 1970. $245 \mathrm{c}$.

Северо-Запад в аграрной истории России / Под ред. В. Н. Никулина. Калининград: Изд-во РГУ им. И. Канта, 2008. 272 с.

Стэндинг Г. Прекариат: новый опасный класс. М.: Ад Маргинем Пресс, 2014. $328 \mathrm{c}$.

Суворов К.И. Исторический опыт КПСС по ликвидации безработицы (1917-1930). М.: Мысль, 1968. 258 с.

Суханов Н.Н. К характеристике российского пролетариата // Современник. 1913. № 4. С. 320-328.

Тощенко Ж. Т. Прекариат: от протокласса к новому классу. М.: Наука, 2018. $350 \mathrm{c}$.

Фёдоров А.Н. Реальная опора советской власти: социально-демографические характеристики городского населения России в 1917-1920 годах (на материалах Центрального Промышленного района) // Журнал исследований социальной политики, 2010. Т. 8. № 1. С. 69-86.

Шабанова М.А. Сезонные строители в сибирском селе // Известия Сибирского отделения Академии наук СССР. Сер. Экономики и прикладной социологии, 1986. № 7. Вып. 2. С. 48-57.

Шабанова М.А. Современное отходничество как социокультурный феномен // Социологические исследования. 1992. № 4. С. 55-63.

Burds J. Peasant dreams and market politics: labor migration and the Russian village, 1861-1905. Pittsburgh (PA): Univ. of Pittsburgh Press, 1998. XIV. 314 p.

Plusnin J., Zausaeva Y., Zhidkevich N., Pozanenko A. Wandering Workers. Mores, Behavior, Way of Life, and Political Status of Domestic Russian Labor Migrants. Stuttgart: Ibidem-Verlag, 2015. 306 p.

Wyckoff D.D. Truck drivers in America. Lexington: Lexington, 1979.

Статья поступила 21.06.2019. 
Для цитирования: Плюснин Ю.М. Российское отходничество: вехи многовековой истории // ЭКО. 2019. № 11. С. 94-115. DOI: 10.30680/ECO01317652-2019-11-94-115.

\section{Summary}

Plusnin, Yu. M., Doct. Sci. (Philosophy), Cand. Sci. (Biology), National Research University - Higher School of Economics, Moscow

\section{Russian Otkhodnichestvo: Milestones of a Centuries-Old History}

Abstract. Otkhodniks are the self-name of Russian internal temporary work migrants. These are commonly seasonal workers, though different from seasonal agricultural workers or from circulatory migrants and gastarbeiters. A lot of them are small business entrepreneurs. But mostly they are hired workers. The key attributes of the otkhodniks are the following: They live permanently in villages and small towns but seek work in the capitals (Moscow and St. Petersburg), or industrial development centers in the North and in Siberia. They do not want to change their permanent residence in order to move closer to their work place. The main labor motivation of these migrant workers is increasing their family welfare. The basic life motivations of otkhodniks are independence, initiative, self-activity.

This paper briefly reviewed the 5-century history of Russian otkhodnichestvo identifying the main causes of this type of migration in the imperial period (XVII-XX century) and over the past 30 years of present time. The author identified factors that stimulate or suppress the migration activity of provincial residents and estimated the current number of otkhodniks comparing them with other estimates for the XVII-XX centuries and revealing the secular dynamics. The author also provided estimates of otkhodniks's structure of employment from the 1990s describing the evolution of modern working migration. The most important features of the evolution are dynamism, variability and expansion. The author concluded that seasonal migrantsotkhodniks are a new class in Russia - the precariat.

Keywords: informal economics; self-emploiment; internal seasonal labor migration; otkhodniks; history of Russian otkhodnichestvo; labor migration types and structure; precariat

\section{References}

Andryushin, E.A. (2012). From the history of the USSR labor law and human resource policy of the Soviet government. Moscow. Novyj Khronograf Publ. 464 p. (In Russ.).

Barsukova, S. Yu. (2003). Informal economy: concepts and structure. Ekonomicheskaya sotsiologiya. Economic Sociology. Vol. 4. No. 4. Pp. 15-36. (In Russ.).

Barsukova, S. Yu. (2004). Informal economy: socio-economic analysis. Moscow. Izdatel'stvo GU VShE Publ. (In Russ.).

Barsukova, S. Yu., Radaev, V.V. (2012). Informal economy in Russia: brief overview. Ekonomicheskaya sotsiologiya. Economic Sociology. Vol. 13. No. 2. Pp. 99-111. (In Russ.).

Burds, J. (1998). Peasant dreams and market politics: labor migration and the Russian village, 1861-1905. Pittsburgh (PA): Univ. of Pittsburgh Press, XIV. 314 p. 
Danilov, V.P. (1974). Engagement of peasants in external wage earning in the 1920s. Istoricheskie zapiski. Historical Notes. (In Russ.).

Delarov, D.I. (1928). The Northern Oblast and its role in the economy of the USSR. Sever. North. Vologda. No. 7-8. Pp. 135-160. (In Russ.).

Fyodorov, A.N. (2010). Real pillar of the Soviet power: social and demographic features of Russia's urban population in 1917-1920 (based on the materials from the Central Industrial region). Zhurnal issledovanij sotsial'noj politiki. The Journal of Social Policy Studies. Vol. 8. No. 1. Pp. 69-86. (In Russ.).

In the shadow of regulation: Informality in the Russian labor market. (2014). Eds. V.E. Gimpel'son, R. I. Kapelyushnikov. Moscow. Izdatelskij dom Vysshej shkoly ekonomiki. 536 p. (In Russ.).

Informal economy. Russia and the world. (1999). Ed. T. Shanin. Moscow. Logos Publ. (In Russ.).

Karyshev, N.A. (1896). Concerning a study of our otkhodnik occupations. Russkoe bogatstvo. Russian Wealth. No. 7. Pp. 1-24. (In Russ.).

Kulisher, I.M. (2004). History of the Russian economy. Chelyabinsk. Socium Publ. 743 p. (In Russ.).

Lenin, V.I. (1971). The Development of Capitalism in Russia. The process of the Formation of a Home Market for Large-Scale Industry. In: V. I. Lenin. Complete set of works. Moscow. Izdatelstvo politicheskoj literatury. Vol. 3. 610 p. (In Russ.).

Mints, L.E. (1926). Engagement of peasants in external wage earnings in the USSR. Moscow. Voprosy truda Publ. (In Russ.).

Mints, L.E. (1929). Agrarian overpopulation and the labor market in the USSR. M.-L. GIZ Publ. (In Russ.).

Mordovtsev, D.L. (1877). A decade of Russian zemstvo. 1864-1875. SPb. 86 p. (In Russ.).

Non-standard employment in the Russian economy. (2006). Eds. V.E. Gimpelson, R. I. Kapelyushnikov. Moscow. Izdatelskij dom GU-VSHE. 400 p. (In Russ.).

Plusnin, J., Zausaeva, Y., Zhidkevich, N., Pozanenko, A. (2015). Wandering Workers. Mores, Behavior, Way of Life, and Political Status of Domestic Russian Labor Migrants. Stuttgart. Ibidem-Verlag. 306 p.

Plusnin, J.M. (2016). Life away from the state: otkhodniks and authority in modern Russia. Voprosy Gosudarstvennogo i Municipal'nogo Upravlenija. Issues of Public Administration. No. 1. Pp. 60-80. (In Russ.).

Radaev, V.V. (1999). The sh adow economy in Russia: a change of contours. Pro et Contra. Vol. 4. No. 1(10). Pp. 5-24. (In Russ.).

Remnev, A.V., Suvorova, N.G. (2010). Controlled Colonization and Spontaneous Migration Processes on Asian Peripheries of Russian Empire. Politeia. No. 3-4 (58-59). Pp. 150-191. (In Russ.).

Ryndzyunsky, P.G. (1970). Engagement of peasants in external wage earnings and the size of the rural population in the 1880s. In: Problemy genezisa kapitalizma. Problems of the Genesis of Capitalism. Moscow. Nauka Publ. 245 p. (In Russ.).

Shabanova, M.A. (1986). Seasonal builders in Siberian villages. Izvestiya Sibirskogo otdeleniya Akademii nauk SSSR. Seria Ekonomiki i prikladnoj sociologii. News of the Siberian Branch of the Academy of Sciences of the USSR. Vol. 2. No. 7. Pp. 48-57. (In Russ.). 
Shabanova, M.A. (1992). Contemporary otkhodnichestvo as a sociocultural phenomenon. Sotsiologicheskie issledovaniya. Sociological Research. No. 4. Pp. 55-63. (In Russ.).

Standing, G. (2014). The Precariat. The new dangerous class. Moscow. Ad Marginem Press. 328 p. (In Russ.).

Sukhanov, N.N. (1913). Concerning the description of the Russian proletariat. Sovremennik. Contemporary. No. 4. Pp. 320-328. (In Russ.).

Suvorov, K.I. (1968). The historical experience of the CPSU on eliminating unemployment (1917-1930). Moscow. Mysl' Publ. 258 p. (In Russ.).

The North-West in the agricultural history of Russia. (2008). Ed. V. N. Nikulin. Kaliningrad. Izdatelstvo RGU im. I. Kanta. 272 p. (In Russ.).

Toshchenko, Zh.T. (2018). Precariat. From Protoclass to New Class. Moscow. Nauka Publ. 350 p. (In Russ.).

Vladimirsky, N.N. (1927). Engagement of peasants from the Kostroma Province in external wage earnings. Kostroma. Izdanie Kostromskogo gubstatotdela. 204 p. (In Russ.).

Wyckoff, D.D. (1979). Truck drivers in America. Lexington, Massachusetts: Lexington Books. 138 p.

For citation: Plusnin, Yu.M. (2019). Russian Otkhodnichestvo: Milestones of a Centuries-Old History. ECO. No. 11. Pp. 94-115. (In Russ.). DOI: 10.30680/ ECO0131-7652-2019-11-94-115. 